\title{
APPLES TO ORANGES? \\ Gendered DAMages in Personal INJURY Litigation: A FOCUS ON INFANT CLAIMS
}

\author{
KATHLEEN RENAUD*
}

\begin{abstract}
For infant plaintiffs, personal injury litigation damage awards for loss of earning capacity are highly speculative. To quantify damages, courts rely on general population statistics and often consider the gender of the plaintiff. This article examines ways in which courts have discounted damages to minor female plaintiffs. The author notes that this discounting broadly occurs in two ways, through the use of gendered statistics and through the application of female specific contingencies. While the courts have justified gender specific damages on the basis that tort law aims to be corrective, the author argues that these practices are no more appropriate than reducing damage awards based on factors such as race or ethnicity. The author concludes that tort law is capable of evolution and it is time that the practice of gender based damages be retired.
\end{abstract}

\section{TABLE OF CONTENTS}

I. INTRODUCTION . . . . . . . . . . . . . . . . . . . . . 207

II. Lost EARning CAPACITY AND the FEMALE PlaintifF . . . . . . . . . . . 210

III. METHODS OF REDUCING COMPENSATION

TO INFANT FEMALE PlainTIFFS $\ldots \ldots \ldots \ldots \ldots \ldots \ldots \ldots \ldots \ldots \ldots \ldots$

A. Step One: The Use of Gendered Income Statistics $\ldots \ldots \ldots 211$

B. STEP TwO: THE USE OF

"FeMAlE" Negative Contingencies $\ldots \ldots \ldots \ldots \ldots \ldots \ldots \ldots 219$

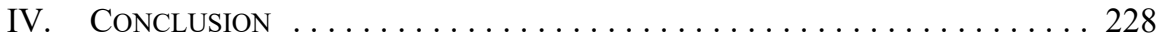

\section{INTRODUCTION}

Loss of earning capacity figures among the largest heads of damage in catastrophic personal injury litigation. The amount an injured plaintiff recovers under this category can profoundly impact the quality of his or her life. While adult plaintiffs offer evidence of their pre-injury qualifications, skills, employment, and income, the exercise remains highly speculative in cases of injured infants. The earlier the injury is sustained in life, such as at birth or early in childhood, the more the courts have relied on general population statistics to quantify the prospective marketplace value of the child — but for his or her injury.

In making this calculation, three factors are commonly assessed:

1. The educational attainment of the child's parent(s);

2. the professional success of the child's parent(s); and

3. the gender of the child.

This article focuses on the third factor.

JD candidate (2019), Faculty of Law, University of Alberta. The author would like to thank Professor Mitchell McInnes and Dorian Simonneaux for their helpful comments and encouragement. This article won first prize in the general category of the 2018 Morrow Essay Competition. 
The general practice across Canadian jurisdictions has been to use male or female income averages depending on the gender of the injured child. ${ }^{1}$ Earning tables organized by gender reflect past and present inequalities faced by women in the workforce who, on average, earn less per annum than men. This automatic application of gendered cohorts, with the male group enjoying a higher average means that, by virtue of being female, injured girls are immediately determined to have a lesser earning capacity than injured boys. In other words, compensation is based on the paradigm that an injury to a boy creates a greater loss than an injury to a girl.

While the courts have recognized that the statistical evidence may be flawed, or its conclusions unsavoury, the tradition remains largely intact. In an attempt to reduce the disparity, lost income may be "grossed up" by an arbitrary percentage to account for future narrowing in income inequality. ${ }^{2}$ In rare cases, gender-neutral income averages may be used depending on the profession the court predicts the plaintiff would have held. ${ }^{3}$ However, only at first glance does this appear to be progress for female plaintiffs.

Usually the career potential of an infant plaintiff is assessed according to the parent of the same gender, meaning that mothers determine the lost career trajectory of injured girls and fathers for injured boys. If the parents are spouses, no attention is paid to the allocation of earning roles within a family unit or to the fact that they are partners in a marital unit of equal economic value. ${ }^{4}$ On occasion, the case law mentions gender parity and the limits of statistical evidence. However, calculations are regularly done without reference to generational differences and socio-historical explanations for why women traditionally have occupied lesser paying professions. For the injured female plaintiff, her career is determined to be one that is generally less lucrative, to which income averages are applied, more often than not, from an exclusively female pool.

Compensation may be reduced further by applying negative contingencies specific to female plaintiffs. These are meant to reflect the time it is presumed she will spend out of the workforce giving birth and raising children. Additional reductions made to an injured girl's loss of earning capacity are sometimes explicitly referred to as "female contingencies," with parenting being viewed as a responsibility and a financial hardship that is uniquely female. ${ }^{5}$ Gender-specific contingencies reflect outdated but enduring assumptions about a woman's exclusive function as caretaker, while no equivalent negative "male" contingencies exist.

The size of the gender pay gap depends on how the earnings are measured. Taken as a whole, if the measurement is hourly wage, women earn $\$ 0.87$ for every dollar earned by men. If the measurement is annual earnings, the gender earnings ratio of women to men is 0.74 , meaning women earn on average $\$ 0.74$ for every dollar earned by men. See Melissa Moyser, "Women and Paid Work" in Statistics Canada, Women in Canada: A Gender-Based Statistical Report, 7th ed, Catalogue No 89-503-X (Ottawa: Statistics Canada, 8 March 2017) at 26 [Statistical Report 2017]. (per MacEachern CJBC dissenting in part; providing a suggested method not applied in the decision). MacCabe v Westlock Roman Catholic Separate School District No 110, 1998 ABQB 809 [MacCabe QB], aff'd in part 2001 ABCA 257 [MacCabe CA]; Terracciano (Guardian ad litem of) v Etheridge, [1997] 7 WWR 185 [Terracciano].

$4 \quad$ Steinebach (Litigation Guardian of) v Fraser Health Authority, 2011 BCCA 302 at paras 66-69 [Steinebach CA] (as a suggested means of analysis not applied in the decision).

MacCabe CA, supra note 3 at paras 124-28. 
The practice of awarding female plaintiffs less than male plaintiffs has been justified on the basis that tort law is corrective, not distributive. Its goal is not to redress society's ills, but to place plaintiffs in the position they would be in but for the injury. Proponents of gendered damages maintain that the use of gender-neutral statistics is an attempt to rectify inequality which is at odds with the restitutio in integrum principle of compensatory damages. They hold that statistics reflect reality and that reality must be replicated, even if the reality is unjust. One appellate court has held that gendered loss of income is analogous to the discriminative but constitutionally acceptable statistics used to calculate insurance premiums. ${ }^{6}$

The use of gender-neutral statistics would not be an attempt, as they argue, to restore society's ills. Instead, it would reduce the degree of speculation that is framed by biases. The amount of extra guesswork distinctly applied to female plaintiffs has the effect of barring access to compensation that would be available to them if they were male. Evidence which inflates the earnings of one gender, while deflating the earnings of the other, does not achieve restitutio in integrum; it sets female plaintiffs back in time. As do negative contingencies applied to children based on their reproductive organs.

The resulting situation for female plaintiffs is not akin to paying more money for car insurance. Tort remedies for personal injury are not dictated by the free market and the standard industry practices of insurance companies. The effect of applying this perspective is to deny equal protection to female victims of injury. Ultimately, gendered damages provide a worse quality of life for a girl injured through no fault of her own. The notion that compensatory damages are entirely incompatible with substantive equality is inconsistent. While tort law strives for an individualized assessment of damages, one must reconcile how earning capacity must rigidly correspond with gendered statistical data, yet the use of other statistical cohorts is rejected. Data organized by categories such as race, religion, native language, and citizenship would narrow the sample size considerably, but these cohorts are not inputted to calculate lost earning capacity. ${ }^{7}$ This demonstrates that methods of assessing compensatory damage can bend when the approach is far too inequitable.

This article argues that gender should no longer be used as a factor in determining damage for loss of earning capacity in infant personal injury litigation. While much of the argument for gender-neutral statistics also applies to adult plaintiffs, treatment of both infant and adult damages is beyond the scope of this analysis. Instead, the focus is on infant plaintiffs because the absence of merit-based evidence for children better illustrates the depth of gender-based discrimination and the practical impact of this discrimination on catastrophically injured females. The cases selected to highlight gendered earning capacity are negligence-based

MacCabe CA, supra note 3 at paras 94-95 citing Zurich Insurance Co v Ontario (Human Rights Commission), [1992] 2 SCR 321 [Zurich].

Statistical Report 2017, supra note 1 ("[g]ender often overlaps with other social characteristics, such as visible minority status, Aboriginal status, immigrant status (i.e., Canadian-born or foreign-born) and class. These social characteristics may intersect, creating diverse labour market experiences among women (and men)" at 3). 
personal injury claims of girls 18 years or younger at the time of injury, litigated primarily in Ontario, British Columbia, and Alberta. ${ }^{8}$

The analysis begins with an introduction to the concept of lost earning capacity and the struggle to reconcile it with gender. It then proceeds to a discussion of the two main means of reducing damages in personal injury litigation where the plaintiff is an infant female: (1) the use of gendered statistics, and (2) the application of female-specific, negative contingencies.

\section{Lost EARning Capacity ANd the Female Plaintiff}

The Supreme Court of Canada has left the concept of lost earning capacity virtually untouched since the "damage trilogy" was decided nearly 40 years ago. ${ }^{9}$ Justice Dickson writing for the Supreme Court in Andrews held that the compensatory principle is a "loss of a capital asset consisting of income-earning capacity," rather than a loss of earnings. ${ }^{10}$ The task is to gaze into the crystal ball to determine what capacity existed prior to the accident: "[a] capital asset has been lost: what was its value?"11 Or, what would have become of the individual from a career potential point of view?

Thornton did not elaborate, as counsel had agreed to an assumed monthly income for the plaintiff. No mention is made of "capacity," instead naming the head of damage "Loss of the Ability to Earn Future Income."12 However, in the third case of the trilogy, Teno, the Supreme Court turned to Lord Denning when faced with what appeared to be the challenge of reconciling gender with earning capacity. Unlike the plaintiffs in Andrews and Thornton, who at the time of their accidents were (1) an employed young man and (2) a boy in high school, the plaintiff in Teno was a four-year-old girl. ${ }^{13}$

Lord Denning spoke of gender as an added complexity in Taylor v. Bristol Omnibus Co., a case involving a claim of lost earning capacity by a male plaintiff who was three-years old at the time of injury:

Who can say what a baby boy will do with his life? He may be in charge of a business and make much money. He may get into a mediocre groove and just pay his way. Or he may be an utter failure. It is even more speculative with a baby girl. She may marry and bring up a large family, but earn nothing herself. Or, she may be a career woman, earning high wages. ${ }^{14}$

Litigation of intentional torts, such as sexual assault and battery, also results in gendered damages but litigation in this area tends to commence when the claimant is well into adulthood, so is not applicable to this analysis. Instead, the cases assessed in this article are predominately medical or vehicular negligence claims.

$9 \quad$ Allen M Linden, Lewis N Klar \& Bruce Feldthusen, Canadian Tort Law: Cases, Notes \& Materials, 14th ed (Toronto: LexisNexis Canada, 2014) at 847 (referring to Andrews v Grand \& Toy Alberta Ltd, [1978] 2 SCR 229 [Andrews]; Thornton v School District No 57 (Prince George), [1978] 2 SCR 267 [Thornton]; Arnold v Teno, [1978] 2 SCR 287 [Teno]).

$10 \quad$ Andrews, ibid at 252.

$11 \quad$ Ibid at 251 (confirming loss of earning capacity as a present loss: The Queen $v$ Jennings, [1966] SCR 532).

Thornton, supra note 9 at 274.

Teno, supra note 9 (the plaintiff, four-year-old Diane Teno, suffered a severe brain injury when she was struck by a car while crossing the street with her brother to make a purchase from an ice cream truck). [1975] 2 All ER 1107 at 1113 (CA). 
Accordingly, the assessment of Diane Teno's lost earning capacity is framed by her potential for motherhood, even though her own mother had a career as a teacher and neither Andrews nor Thornton considered the future family obligations of the plaintiff. The premise that it is all the more uncertain when it comes to girls guided the Supreme Court to hold that it would have been unfair to the defendants to presume that the female plaintiff would have achieved even the same level of earnings as her mother (her father's success was not assessed). In the end, Diane Teno as a "lost capital asset" was determined to be slightly above the poverty line. The result was startling, especially since Justice Spence introduced the damages portion of the judgment by writing, with respect to personal damage claims: "the prime purpose of the Court is to assure that the terribly injured plaintiff should be adequately cared for during the rest of her life." 15

The issue of distinguishing female earning capacity from male earning capacity has yet to be brought before the Supreme Court of Canada. The facts of Toneguzzo-Norvell (Guardian ad litem of) v. Burnaby Hospital appeared to set the stage for a restatement of Teno in 1994, but the Supreme Court did not proceed because a proper evidentiary foundation had not been laid by the lower courts. ${ }^{16}$ At the British Columbia trial and appellate courts, plaintiff's counsel requested that damage for loss of earning capacity be assessed according to the admitted statistics on women's income. ${ }^{17}$ At the final stage of litigation, however, this counsel argued for damage to be calculated instead with reference to male statistics, despite never entering such statistical evidence into the record. At the Supreme Court, the plaintiff's loss of earning capacity remained the amount advocated by her counsel at the lower courts. ${ }^{18}$

Counsel for female plaintiffs have the option of tendering gender-neutral evidence when arguing this head of damage but, perhaps because of the heightened risk of appeal, this has been the exception rather than the rule. ${ }^{19}$ Lord Denning's musing on women in the workforce in 1975 still carries the day. As will be demonstrated, defendants often stand to gain at least $\$ 100,000$ by appealing the decision of a trial judge who did not base the lost earnings of an injured girl, at least in part, on the idea that females are born with a lower earning capacity than males.

\section{Methods of Reducing Compensation to Infant Female Plaintiffs}

\section{A. STEP One: The USE OF Gendered InCome STAtistics}

Imagine this case scenario: four-year old fraternal twins, Michael and Mary, are profoundly and permanently injured due to someone else's negligence. Liability is admitted and experts on both sides agree that their identical injuries prevent them from ever becoming independent and earning incomes. Their parents have bachelor's degrees and are chartered

[1994] 1 SCR 114 at 125 [Toneguzzo-Norvell SCC]. Jessica Toneguzzo-Norvell suffered a catastrophic brain injury at birth as a result of the defendant physician's negligence.

Toneguzzo-Norvell v Burnaby Hospital, 1991 CanLII 579 at 14-16 (BCSC) [Toneguzzo-Norvell BCSC]

Toneguzzo-Norvell SCC, supra note 16 at 125.

MacCabe, supra note 3; cf Steinebach CA, supra note 4. 
professional accountants (CPAs). Assume the gender pay gap of Canadian CPAs is replicated in the earnings of the spouses: the father earns an annual average of $\$ 117,000$, while the mother earns $\$ 98,000 .^{20}$ Michael's loss of earning capacity would be $\$ 3,276,000$, while Mary's would be $\$ 2,744,000 .^{21}$ Based only on her gender, Mary's damages would be $\$ 532,000$ less than the amount awarded to her twin.

Now imagine that the twins' father is still a CPA with the same earnings, but their mother works in business management and earns $\$ 62,900$, the average amount for women in this type of occupation. ${ }^{22}$ Michael's loss of earning capacity would remain at $\$ 3,276,000$, but his sister's estimate would drop to $\$ 1,680,000 .{ }^{23}$ Michael would receive over $\$ 1.5$ million more in compensation for his injuries than his twin sister because he is male.

Unsurprisingly, litigation over the lost earning capacity of fraternal twins of different genders does not appear in Canadian case law. The odds of the Mary and Michael example being replicated at trial are improbable for many reasons, starting with the unlikelihood of identical injuries caused by negligence, creating equal impairments to twin children, one being male and the other female. Additionally, the counsel tasked with arguing significantly less for the female twin may choose to settle out of court. The scenario, however, does provide an accurate illustration of the current methodology that disadvantages female plaintiffs, as can be seen in A.T.-B. v. Mah, a 2012 decision of the Alberta Court of Queen's Bench. $^{24}$

"A" was born with a severe brain injury manifested in profound cerebral palsy. At trial, her serious and permanent impairments were found to be due to the negligence of an obstetrician/gynecologist. The parties agreed that she would never have the capacity for paid employment. Plaintiff's counsel argued that A's lost earning capacity should not be assessed in a way that reinforces "historic and inequitable gender-based pay differences." 25 However, counsel also agreed with the defendants on the general proposition that women work fewer hours than men. This appeared to frame the trial judge's decision to calculate A's lost earning capacity using female-only earning data. ${ }^{26}$

The crucial difference between men and women in the workforce, suggested by Justice Graesser, is a question of behaviour. The gender pay gap among university graduates, which he acknowledged as sizeable, is because women choose career paths that are not as lucrative as those taken by men. He held that this discrepancy was not the product of discrimination or inequality, but that men and women in the workforce were comparable to "apples" and

Chartered Professional Accountants of Canada, "2013 CPA Profession Compensation Study: Supplementary Report Gender Differences” (Toronto: CPA Canada, 2014) at 1.

Loss of earning capacity calculated for both children with a 20 percent deduction for contingencies and 35-year record of employment.

Cara Williams, "Economic Well-being," in Statistics Canada, Women in Canada: A Gender-based Statistical Report, 6th ed, Catalogue No 89-503-X (Ottawa: Statistics Canada, 11 March 2016) at 16 [Statistical Report 2010].

See supra note 21.

2012 ABQB 777 [AT]. The question of "apples" and "oranges" which appears in the title of this article is a reference to $A T$ which suggests that the educational, professional, and income-earning patterns of men and women should be viewed distinctly when assessing damage for lost earning capacity (at para 747).

Ibid at para 739 .

Ibid at paras 737, 746 . 
"oranges." ${ }^{27}$ He wrote: "A., as a female, can be anticipated to choose a university program that is more typical of female students, leading to a job more typically occupied by a female, and then being paid an income that is typical of the amounts reported by Statistics Canada." 28

The exact quantum of damage was not released as part of the judgment. We know A's lost earning capacity was based on general statistics from an all-female pool of workers with bachelor's degrees, even though both of her parents had graduate degrees in psychology. If the figure chosen to represent the average earnings of female bachelor's degree holders was drawn from a recent Statistics Canada report, A's annual earnings would have been assessed at $\$ 64,420 .^{29}$ This is in contrast to the mean earnings of male bachelor's degree holders of $\$ 87,543$, which replicates almost perfectly the gender earnings ratio of women to men. ${ }^{30}$ If A worked for 36 years, as determined at trial, she would have a lost earning capacity of $\$ 2,319,120$ before the application of contingencies. Had A been a boy, however, the lost earning capacity before contingencies would have been $\$ 3,151,548$ — or $\$ 832,428$ higher.

In response to this judgment, Jamie Cassels and Elizabeth Adjin-Tettey rightly point out that assumptions about women's "choices" should be treated with caution. ${ }^{31}$ The same heed should be paid to all economically undervalued groups when taken as a whole. The assumption that depressed financial attainment is the result of simple decision-making is one made without a socio-historical appreciation for how marginalized groups come to be. It also ignores the systemic discrimination that pervades our modern-day workforce. That there may be flaws in the use of gendered statistics was raised by Justice McLachlin (as she then was) in Toneguzzo-Norvell, but this observation does not appear in the case of infant A.

In Toneguzzo-Norvell, Justice McLachlin highlighted that the Supreme Court of Canada had yet to hear arguments on alternatives to gendered statistics for loss of earning capacity. Writing for the Supreme Court, she drew attention to the fact that "earning tables for women reflect past inequities which have historically resulted in women on average earning less than men." ${ }^{\prime 2}$ She took a different approach to Justice Spence in Teno, whose perspective on restitutio in integrum was that it would be unfair to the defendants to award the plaintiff damages based on the earnings of her mother's teacher salary. Adding the perspective of the plaintiff to restitutio in integrum, Justice McLachlin wrote that the inequities inherent in gendered statistics arguably should not be imposed on the infant female. ${ }^{33}$

Yet, without a palpable and overriding error by the trial judge, Justice McLachlin held that the Supreme Court must await another case to hear arguments on the use of this gendered evidence. The Supreme Court will only interfere when it finds that in coming to the

Ibid at para 747 .

Ibid.

Marc Frenette \& Kristyn Frank, "Earnings of Postsecondary Graduates by Detailed Field of Study" in Statistics Canada, Economic Insights, Catalogue No 11-626-X — No 056 (Ottawa: Statistics Canada, 8 March 2016) at 3.

30 Ibid; Statistical Report 2017, supra note 1 (the gender earnings ratio of women to men is 0.74 , or women earn on average $\$ 0.74$ for every dollar earned by men); in the case of plaintiff $A$, the ratio of women to men for bachelor's degree graduates is 0.736 .

31 Jamie Cassels \& Elizabeth Adjin-Tettey, Remedies: The Law of Damages, 3rd ed (Toronto: Irwin Law, 2014) at 177.

Toneguzzo-Norvell SCC, supra note 16 at 124.

Ibid. 
conclusions: "[the trial judge] has made a manifest error, has ignored conclusive or relevant evidence, has misunderstood the evidence, or has drawn erroneous conclusions from it." ${ }^{\prime 34}$

Justice Hogarth of the British Columbia Supreme Court had based his calculations on the gendered statistics advanced by the plaintiff's counsel, which he held "can only be a guide to a global assessment as opposed to a mathematical formula." ${ }^{35}$ Consequently his assessment of the plaintiff's damage was even more favourable than what had been proposed by her counsel and was affirmed generally by the Court of Appeal. He had considered "the trend to increase and equalize the salaries of women with those of men" in awarding slightly larger damages for lost earning capacity, instead of relying exclusively on the earning tables for females. ${ }^{36}$

Although the issue of female earning capacity has not reappeared before the Supreme Court, Toneguzzo-Norvell signaled a modest shift, among the lower courts, away from the rigid application of gendered statistics. It is now common for trial judges to increase the amount of lost earning capacity of a female plaintiff by a given percentage to account for growing gender equality in the marketplace - provided the judge does not go too far. ${ }^{37}$ As in AT, the plaintiff (Mirella) in Steinebach v. Fraser Health Authority developed severe cerebral palsy as a result of negligent medical care; she will never work and will always depend on her parents for basic care. However, instead of fully rejecting a progressive approach to lost earning capacity, the British Columbia Court of Appeal held that the trial judge had no basis to be so optimistic about the future of female earnings.

At trial, both plaintiff and defendant experts submitted earning capacity projections based on the worker class "females with one to two years of post-secondary education." 38 Their results were $\$ 547,850$ and $\$ 517,400$, respectively, to which Justice Pitfield accepted an approximate mean amount of $\$ 532,000$, or a 3 percent reduction to the plaintiff's estimate. ${ }^{39}$ To illustrate the discrepancy in female and male earnings created by this statistical average approach, the plaintiff's expert presented the income projection for "a male with one to two years of post-secondary education," which was $\$ 945,000 .{ }^{40}$ The defendant expert did not submit a comparative male sum but, applying the same 3 percent reduction, Justice Pitfield estimated the value of male earning capacity at $\$ 916,600$. In other words, the child's lost earning capacity would have been an additional $\$ 384,600$ had Mirella been a boy approximately 40 percent more. ${ }^{41}$

Finding this discrepancy highly inequitable, the trial judge proceeded on the assumption that with the ongoing passage of time, the disparity in earnings between the genders will

Ibid at 121, cited in Housen v Nikolaisen, 2002 SCC 33 at para 159.

Toneguzzo-Norvell BCSC, supra note 17 at 14.

Toneguzzo-Norvell SCC, supra note 16 at 124, citing Toneguzzo-Norvell BCSC, ibid at 15 .

Gray v Macklin (2000), 4 CCLT (3d) 13 at para 205 (Ont Sup Ct J) [Gray] (applying a wage gap of 90 percent to a 15-year-old female); cf Steinebach v Fraser Health Authority, 2010 BCSC 832 [Steinebach BCSC] (applying a wage gap of 97 percent), rev'd in part by Steinebach CA, supra note 4. See also Tucker CA, supra note 2.

Steinebach BCSC, ibid at para 165.

Ibid at paras 166-67.

Ibid at para 168 .

Ibid. 
diminish. ${ }^{42}$ Quoting Audet v. Bates, a 1998 decision of his also involving a profoundly disabled female infant, he held:

\begin{abstract}
I see no logical or compelling reason to differentiate between male and female earning capacity when making an assessment in relation to an infant whose work and education prospects cannot be identified or characterized with any precision. There is good reason to subscribe to the opposite view which is that in the context of emerging community standards, an infant who is a female will be afforded the opportunity in the course of her working life to earn income as an infant who is a male. ${ }^{43}$
\end{abstract}

He reduced the male figure of $\$ 916,600$ by another $3 \%$ for a value of $\$ 890,000$, or a gender earnings ratio of $0.97 .^{44}$

The Court of Appeal held that this award was so inordinately high as to be a wholly erroneous estimate of the damage. While the trial judge was entitled to take a degree of judicial notice that women's earnings will improve, it was a palpable and overriding error to predict the 40 percent present gap between men and women with one to two years of postsecondary education would be almost entirely eliminated in the near future. ${ }^{45}$ Mirella's lost earing capacity was reduced from $\$ 890,000$ to $\$ 750,000$ because the 97 percent wage disparity was not based on economic trends before the Court. ${ }^{46}$ However, where female data has been grossed up by the courts, it is unclear from any of the cases canvassed that the percentage of increase was based on tendered evidence. Instead, it appears a speculative topup to female earnings is acceptable provided the forecast is not too generous.

Rather than have judges safely predict the future of the gender wage gap, occasionally the courts have been persuaded that the infant female plaintiff would have grown up to exhibit "male capacity." Proving that the child, for example, possesses a particularly strong work ethic, is of above-average intelligence, or has "career women" in the family, is a hurdle faced by counsel for female plaintiffs seeking the use of male or gender-neutral income statistics. Success depends largely on the child's family background and her age, with teenagers naturally better poised than infants to offer indicia of male careerism and accomplishment. This approach creates a specifically-female evidentiary burden that in no way lessens the level of unpredictability surrounding the quantification of damages for injured girls. ${ }^{47}$

In Terracciano (Guardian ad litem of) v. Etheridge ${ }^{48}$ the case was made for departing from female-only statistics, not because of methodological flaws but because sufficient evidence of the plaintiff's individual attributes could be tendered. The plaintiff, Elisabetta Terracciano, was a "lively, energetic and ambitious" 16-year-old who was made paraplegic

$42 \quad$ Ibid at para 172.

43 Ibid at para 170, citing Audet v Bates, 1998 CanLII 6786 at para 76 (BCSC) [Audet].

$44 \quad$ Steinebach BCSC, ibid at para 174.

Steinebach CA, supra note 4 at para 42 . The overall median gender earnings ratio of women to men in 2011 was 0.665 while the average hourly wage was the present $\$ 0.87$ of every dollar: see Statistics Canada, "Table 11-10-0143-01: Average Female and Male Earnings and Female-to-Male Earnings Ratio," online: <www5.statcan.gc.ca/cansim/a26?lang=eng\&id=202010>; René Morissette, Garnett Picot \& Yuqian Lu, The Evolution of Canadian Wages over the Last Three Decades, Catalogue No $11 \mathrm{~F} 0019 \mathrm{~N}$ - No 347 (Ottawa: Statistics Canada, 2013).

46 Steinebach, ibid at para 43.

$47 \quad$ Elizabeth Adjin-Tettey, "Replicating and Perpetuating Inequalities in Personal Injury Claims Through Female-Specific Contingencies" (2004) 49:2 McGill LJ 309 at 317. Supra note 3. 
by the negligence of another driver. ${ }^{49}$ Her counsel asked the court to award compensation for lost earning capacity on the basis of average earnings of men with more than one year postsecondary education, reduced by 6 percent to replicate the anticipated earnings of Elisabetta's older sister. ${ }^{50}$ In contrast, the defence requested the figure to be based on statistical averages for women, discounted for negative contingencies and reduced by 30 percent to allow for future earnings; the defendants argued that she would be able to work a menial, part-time job. The different methodologies produced a discrepancy of $\$ 805,000$ : $\$ 1,155,000$ advanced by the plaintiff and $\$ 350,000$ by the defendant. ${ }^{51}$

Justice Saunders found the plaintiff's submission, as a matter of fact, to be a more realistic approximate of Elisabetta's loss. Rejecting the defendant's approach, she wrote:

\begin{abstract}
Apart from the fact that these statistics perpetuate historical inequality between men and women in average earning ability, and that they have hidden in them serious discounts for lower and sporadic participation in the labour market which are duplicated by many of the negative contingencies used by economists to massage the numbers downward, such statistics may provide little assistance in predicting the future of a particular female plaintiff. ${ }^{52}$
\end{abstract}

The courts often take labour market statistics to be sufficiently predictive and therefore a sound basis for assessing future damages; in dealing with interest rates, for example, they may provide the best evidence available. ${ }^{53}$ However, actuarial conclusions can distract from the duty of the court in personal injury litigation, which is not to assess the average person's loss but to assess the individual plaintiff's loss in the context of his or her personal circumstances. Accordingly, Elisabetta's likeable personality, established work history, and her family's industriousness were relevant in determining a lost earning capacity of $\$ 950,000$, through the use of slightly discounted male income statistics.

But what if Elisabetta did not, for example, have "good examples in her family of women in the workplace?"54 Or, what if she had been injured at birth or as a toddler, like Mirella Steinebach or Diane Teno? With no evidence of school or work performance, this strategy becomes all the more challenging. It requires greater time and money to build the plaintiff's case because the plaintiff has the burden of proving she would have pursued a typically "male" pattern - simply to avoid being slotted into the financially depressed, all-female cohort. ${ }^{55}$ Justice Saunders' firm criticism of gendered statistics suggests perhaps she would

\footnotetext{
Ibid at para 83 .

Ibid at para 86 .

Ibid at paras $75-76$.

Ibid at para 80 .

Ibid at para 77, citing Lewis $v$ Todd, [1980] 2 SCR 694.

Ibid at para 85 .

Cassels \& Adjin-Tettey, supra note 31 at 175; cf Grassick (Guardian ad litem of) v Swanburg, 2015 BCSC 2355. Like Elisabetta, Stirling Grassick was injured severely at 16 years of age because of a negligent driver. Albeit not paraplegic, he suffered a brain injury that rendered him not-competitively employable. His father is a truck driver and his mother is an executive assistant. Not only was his prospective career assessed to be in engineering, Justice Loo gleaned that Stirling would have been management material and awarded $\$ 3$ million in lost earning capacity that included a 24 percent reduction for contingencies (ibid at para 204). This is not to suggest that she erred in finding such great capacity. Children often surpass the educational and professional accomplishments of their parents. Nevertheless, one wonders whether such elevated capacity would have been considered had Stirling been a girl. Such resolute acceptance of a girl's prospective financial success simply does not exist in Canadian case law.
} 
have made an effort to avoid defaulting to female earnings, even without evidence of Elisabetta's personality and family history. She highlights the paradox that it is obviously unjust to divide capacity along racial lines while gender division remains somehow acceptable, writing: "it may be as inappropriately discriminatory to discount an award solely on statistics framed on gender as it would be to discount an award on considerations of race or ethnic origin." ${ }^{, 56}$

Yet, it is ultimately unclear how Justice Saunders would have approached the capacity of a younger female plaintiff. Elisabetta's individualized assessment was based on the premise that she had just as much potential as a boy, but it does not offer an egalitarian methodology that could be used by plaintiffs of either gender. ${ }^{57}$

\section{THE SOLUTION}

The solution is to use average income statistics for all infant plaintiffs regardless of gender. ${ }^{58}$ This is a simpler approach than the case-by-case methods that currently only apply to female plaintiffs. Non-gendered statistics would eliminate the risk of an appeal, where a trial judge predicts too much wage equality, for instance, and it would end arguments over the potential for "male qualities" in an infant female. The use of gender-neutral averages would bring greater consistency and predictability to the quantification of lost earning capacity, reducing litigation and saving costs. Proponents of gendered statistics, needlessly fearing a windfall for female plaintiffs, eventually must acknowledge that restitutio in integrum is not achieved by the present method of overcompensating one half of claimants while undercompensating the other half.

Imagine that instead of a girl, the third case in the "damage trilogy" involved a 4-year-old boy from a generally financially-depressed ethnic population. Would the case law have been allowed to develop in way that explicitly distinguishes "white" and "non-white" plaintiffs? Would trial judges be grossing up awards for future wage equality among races? Would counsel face an evidentiary burden to prove that their non-white client is just as capable as one who is white? Would white tendencies and advantages need to be demonstrated to avoid placement in the lesser compensated cohort? Logically, the same prejudiced restitutio in integrum argument could have been made..$^{59}$

The fixation on gender is perhaps because non-statisticians recognize male and female cohorts as a common feature of general statistics, like age, race, and language. However, the use of gendered cohorts in the assessment of damages is not an actuarial error. Rather, it is

Terracciano, supra note 3 at para 81 .

Mitchell McInnes, "The Gendered Earnings Proposal in Tort Law" (1998) 77:1- 2 Can Bar Rev 152 at 166-67; cf Shaw (Guardian of) v Arnold, 1998 CanLII 5575 (BCSC) (applying Toneguzzo-Norvell SCC, supra note 16 and Terracciano, ibid, Justice Collver used a "mean average" between the earnings of men and women for the lost earning capacity of a 15-year-old female at para 69).

Cassels \& Adjin-Tettey, supra note 31 at 178.

Racial biases can creep into the quantification of lost earning capacity in other ways. For example, the case law demonstrates that an assumption of upward mobility is more readily applied to non-Indigenous plaintiffs than Indigenous plaintiffs. Unlike gender, however, race or ethnicity have not been treated as a mandatory part of the equation used to calculate the lost earning capacity of infant plaintiffs in personal injury litigation. For an intersectional analysis of race and gender, see Jamie Cassels, "(In)Equality and the Law of Tort: Gender, Race and the Assessment of Damages" (1995) 17:2 Adv Q 158; Cassels \& Adjin-Tettey, ibid at 170-72. 
a court sanctioned approach which is firmly rooted in the 1970s. The Supreme Court recently addressed the dangers of deferring automatically to a non-legal specialist's method of categorizing individuals, when the categorization itself does not require expert knowledge. In Saadati v. Moorhead, Justice Brown drew attention to the excessive reliance in cases of mental injury on psychiatric classifications, specifically the categories contained in the Diagnostic and Statistical Manual of Mental Disorders published by the American Psychiatric Association. ${ }^{60}$ Although the issue in Saadati was causation, an analogy may be drawn that deference to the actuarial practice of classifying income projections according to gender is not a legal requirement.

Examples from Ontario and British Columbia demonstrate the application of genderneutral statistics for infant, female plaintiffs, without a gross up or a demonstration of male capacity. In 2005, the Ontario Court of Appeal in Walker v. Ritchie upheld a decision to apply gender-neutral earning statistics to the lost earning capacity of a 17-year-old female plaintiff. ${ }^{61}$ Stephanie Walker was a grade 12 student when she was catastrophically injured by a negligent driver. Before the collision, she had above-average grades and was an outstanding high school athlete. The trial judge based damage for lost earning capacity on the average earnings of all university graduates, finding Stephanie likely would have been attracted to university programs in human kinetics or in teaching, with a physical education specialty:

The choice of the general average figures for university graduates seems especially appropriate here where the court is attempting to make a forecast stretching many years into the future, and where a couple of the suggested future professions, barring the accident, are teaching in which pay equity has been achieved, and human kinetics, where a good deal of the employment is with government or government supported institutions, where pay equity is mandated. ${ }^{62}$

Citing Justice Saunders' criticisms of gendered statistics in Terracciano, Justice Brockenshire determined gender-neutral evidence best reflected Stephanie's real and substantial risk of future pecuniary loss. ${ }^{63}$ Her lost earning capacity was estimated at roughly $\$ 1.4$ million. ${ }^{64}$

In upholding his decision, the Court of Appeal held that while damages must not be calculated in a way that overcompensates the individual: "a court must be equally cognizant of the fact that gender-based earnings statistics are grounded in retrospective historical data that may no longer accurately project the income a person would achieve in the future." ${ }^{\circ 5}$ The Court of Appeal held that the trial judge did not err in his choice of statistics and that the use of non gendered data did not hamper an individualized approach to the assessment of earning capacity. It was found that he decided to use gender-neutral statistics in the context of all the

Saadati $v$ Moorhead, 2017 SCC 28 at paras 30-31 [Saadati].

(2005), 31 CCLT (3d) 205 (CA) [Walker CA].

Walker v Ritchie, 2003 CanLII 17106 (Ont Sup Ct J) at para 135 [Walker Trial]. Pay equity may be mandated in teaching, but the gender earnings ratio of women to men was 0.83. See Statistical Report 2010, supra note 22 at 16.

63 Walker Trial, ibid at paras 133-35 (damage for lost earning capacity was discounted by 10 percent to reflect the chance Stephanie would have attended a community college instead, as she had not made plans for post-secondary before the injury (ibid at para 141)).

$64 \quad$ Ibid at para 143

65 Walker CA, supra note 61 at para 45. 
evidence before him. It is unclear if any weight was placed on the particular fact that the careers chosen for her have existing, mandated wage parity between genders.

Nevertheless, in 2009 the British Columbia Supreme Court used gender-neutral statistics for the lost earning capacity of an infant female without reference to gender wage parity in certain professions. In Ediger (Guardian ad litem of) $v$. Johnston, the trial judge awarded Cassidy Ediger damages corresponding to the average person with a bachelor's degree or teaching certificate. ${ }^{66}$ Cassidy's severe cerebral palsy developed due to negligent obstetrical care around the time of her birth and no assessment of her career potential could be evidenced from her directly. Rather, Justice Holmes inferred a strong work ethic from Cassidy's parents, noting her supportive and stable immediate family and the unlikelihood she would have departed from the social model into which she was born. The fact that she is female was raised only in reference to the undisputed statistical information concerning the percentage of young females with a post-secondary, non-university certificate. No mention of gendered statistics is made in the judgment. ${ }^{67}$

Some trial judges are receptive to the use of gender-neutral statistics, and are even encouraging. ${ }^{68}$ However, ending discrimination in damages is only partially addressed by way of earnings data. At first glance, a judgment may appear to exemplify gender-neutral damage for lost earning capacity, yet the size of the percentage for negative contingencies, and sometimes its accompanying reasoning, reveals a continued disparity. The second method of reducing compensation for infant female plaintiffs is arguably even more speculative and just as worthy of retirement.

\section{B. STEP TWO: THE USE OF \\ "Female" Negative CONTINGEnCiES}

It is a general practice to apply a contingency deduction to damage for lost earning capacity. Damage may be reduced by a chosen percentage because even if no injury had occurred, the earnings of the plaintiff still would have been exposed to income-reducing factors such as illness and redundancy. While the application of negative contingencies is not mandatory, its usage predates the "damage trilogy" and in practice it has become a staple component of damage calculations, commonly set at a 20 percent reduction. ${ }^{69}$ Applied to a 30 -year work span, a 20 percent discount for negative contingencies means that the plaintiff would not receive any income for six full years (or 1 in 5 years), including no benefits from employment insurance or assistance programs - a proposition the Supreme Court struggled with in the 1970 s, at least with respect to male plaintiffs. ${ }^{70}$

BCSC 386 [Ediger BCSC]. Damage for lost earning capacity was discounted by 20 percent to reflect the chance Cassidy instead would have achieved a college diploma, as only one of her parents had a university degree.

The trial decision was overturned by the British Columbia Court of Appeal on causation, but restored by the Supreme Court of Canada: Ediger (Guardian ad Litem of) v Johnston, 2011 BCCA 253, rev'd 2013 SCC 18.

Rudd v Hamiota Feedlot Ltd, 2006 MBQB 22 at para 99 (lamenting the lack of gender-neutral statistics presented to him in an occupational health and safety case involving an 18-year-old female).

Andrews, supra note 9 at 253; Thornton, supra note 9 at 283.

Cassels \& Adjin-Tettey, supra note 31 at 165. 
In Andrews, Justice Dickson was skeptical of the 20 percent reduction in lost earning capacity applied by the lower courts. ${ }^{71}$ First, these contingencies are already reflected in the average earnings statistics used to project future income. Second, 20 percent assumes higher misfortune than the average individual suffers since the plaintiff may just as well have benefitted from paid bonuses and paid sick days. Additionally, the 20 percent reduction does not appear to take into account the many public and private schemes that protect or cushion against these negative factors. The figure, "although not entirely satisfactory," was accepted nevertheless, with the instruction that a higher degree of specificity supported by evidence be established in future trials. ${ }^{72}$ In Thornton, Justice Dickson upheld a 10 percent reduction for negative contingencies. ${ }^{73}$ However, the Supreme Court returned to 20 percent in Teno without identifying a more precise factual basis for such increased hardship. Diane Teno's lost earning capacity — which already had been determined to be 25 percent less than her mother's proven income - was reduced by another 20 percent for negative contingencies. It is not a stretch to infer that the increase in negative contingencies was based on the simple fact that Diane was a girl.

Since average earnings statistics include the net of negative contingencies, Justice Dickson's caution that any additional reductions be rooted in the evidence is the logical corollary. After all, earnings tables separated by gender already account for a greater percentage of negative contingencies experienced by women generally, who have a higher rate of non-participation in the workforce than men when taken as a whole. ${ }^{74}$ If the lost earning capacity of a female plaintiff, whose damage is calculated using all-female income statistics, is reduced further by a set percentage for negative contingencies, the defendant is handed a "double discount" on the plaintiff"s compensation. In other words, the female plaintiff will achieve a certain percentage less than the female average.

This was illustrated in Crawford (Litigation Guardian of) v. Penney, a medical negligence case involving a female plaintiff who was catastrophically and permanently injured at birth. ${ }^{75}$ The trial judge estimated Melissa Crawford's lost earning capacity using exclusively female income statistics of community college graduates in Ontario. Yet, an additional 10 percent reduction was made to the amount for setbacks such as illness and providing childcare, notwithstanding Justice Power's acknowledgement that these reasons for non-participation were already built into the average earnings tables for women. ${ }^{76}$ It was not established that Melissa, if she had not been injured, would have taken more time out of the workforce than the average woman with a community college qualification. In fact, Justice Power recognized that Melissa came from a family with a particularly strong work ethic, describing the Crawford family history as "one of academic success as well as full time and long term employment." ${ }^{\text {" } 77}$ Rather, the additional 10 percent for negative contingencies was simply a compromise with the defendant, who had proposed a deduction of 32 percent be applied to Melissa's future income, which already was depressed having been drawn from statistics of

Supra note 9 at 253 .

Ibid at 254.

Supra note 9 at 285.

Adjin-Tettey, supra note 47 at 318.

(2003), 14 CCLT (3d) 60 (Ont Sup Ct J) [Crawford], cited in ibid.

Crawford, ibid at paras 296-97.

Ibid at para 293. 
an exclusively female pool. In the end, $\$ 139,400$ was stricken from Melissa's damages for lost earning capacity, without a factual basis to support it. ${ }^{78}$

The courts have identified the problem with "double-discounting" over the last couple of decades. ${ }^{79}$ Crawford today can be considered an outlier. Instead of a "double discount," a much larger deduction for negative contingencies tends to be made to the lost earning capacity of a female infant plaintiff if: (1) her lost earning capacity was calculated using average male or gender-neutral income statistics, or (2) her lost earning capacity was grossed up to account for growing income equality. ${ }^{80}$ This approach often appears in cases that are heralded as progress for the female plaintiff.

In Tucker, the majority of the British Columbia Court of Appeal upheld the decision of the trial judge to apply, as a first step, male earnings statistics to the lost earning capacity of the female plaintiff. ${ }^{81}$ In his reasons at trial, Justice Finch (as he was then) wrote:

I accept, as a starting point, that the measure of the plaintiff's earning capacity should not be limited by statistics based upon her sex. Before the accident the plaintiff was a bright little girl growing up in a stable home environment. In Canada, no educational or vocational opportunities were excluded to her. She could have become a doctor, lawyer or business person. Or, in line with her childhood wish, a veterinarian. ${ }^{82}$

Before her injury in a motor vehicle collision, Brandi Tucker "was an intelligent, healthy well-adjusted eight year old who did well at school."83 After the accident, she was completely unemployable for all practical purposes as an adult. Justice Finch accepted that the measure of her lost earning capacity was the equivalent of the average university educated male in British Columbia, which at the time was $\$ 947,000$. However, negative contingencies were then applied with reference to Justice Spence's calculations in Teno. Since Diane Teno's lost earning capacity was estimated to be much lower than that of Brandi, Justice Finch reasoned that a higher percentage for negative contingencies should be applied to Brandi's damage — an astonishing 63 percent. Although Brandi's lost earning capacity was not said to have been limited by her gender, it ultimately was valued at $\$ 350,000$ - barely above the average lifetime earnings of all females at $\$ 302,000$. $^{84}$

A similar egalitarian sentiment was expressed in Audet, in which Justice Pitfield used gender-neutral statistics to determine the lost earning capacity of a five-year-old girl named Teddy. ${ }^{85}$ He wrote that he was not prepared to take the historical gap in earnings between the genders into account where the plaintiff was injured as an infant. Instead, he combined the averages of male and female earnings for individuals with two years of post-secondary

Ibid at paras 294-99 (the figure is the difference between $\$ 41,000$ for 34 years and $\$ 36,900$ for 34 years, or the application of a 10 percent reduction to Melissa's projected annual earnings over her working life). Spehar v Beazley, 2002 BCSC 1104 at para 46 (see also McInnes, supra note 57 at 154).

Gray, supra note 37 at para 205 (after grossing up the wage gap to 90 percent, the lost earning capacity of the 15 -year-old female plaintiff was reduced by 20 percent for negative contingencies).

Supra note 2.

Tucker (Public Trustee of) v Asleson, 1991 CarswellBC 1997 at para 236 (BCSC).

Ibid at para 207.

Ibid at para 239; Tucker CA, supra note 2, MacEachern CJBC (" $\mathrm{t}]$ he present value of average earnings for university-educated females, discounted for contingencies of death, disability, unemployment and an upward adjustment for non-participation in the labour force, is $\$ 524,000$ " at 529 [emphasis added]). Supra note 43 . 
education or a university degree. However, a 30 percent reduction for negative contingencies was applied to lost earning capacity for a final amount of $\$ 560,000$. The 30 percent in negative contingencies was meant to reflect: "lifestyle choice and the likelihood that community standards of responsibility will afford Teddy an opportunity to engage in some form of remunerative employment." ${ }^{" 86}$

Considering the profundity of Teddy's brain injury — she was non-verbal with serious mobility issues and poor fine motor coordination - realistically, "lifestyle choice" was the reason for the 30 percent deduction, although it was never defined in the judgment. Justice Groberman in Steinebach specified that lifestyle choices were patterns of earning related to child-bearing and child rearing. ${ }^{87}$

Unlike the cases discussed above, there was no room for misunderstanding in MacCabe,

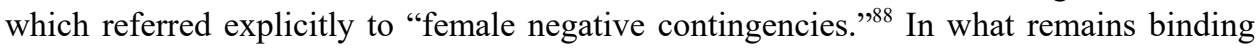
precedent in Alberta, the Court of Appeal in 2001 held that it was an error in legal principle for the trial judge not to have taken into account negative contingencies associated with childbirth and childcare in the assessment of the plaintiff's lost earning capacity. ${ }^{89}$ Margaret MacCabe was a bright, active 16-year-old girl who was injured in her grade 11 gym class, causing her to become quadriplegic. At trial, Justice Johnstone refused to sanction the "reality" of pay inequality in assessing Margaret's lost earning capacity:

\footnotetext{
It is entirely inappropriate that any assessment I make continues to reflect historic wage inequities.... The courts have judicially recognized in tort law the historical discriminatory wage practices between males and females. The courts have endeavoured to alleviate this discrimination with the use of male or female wage tables modified by either negative or positive contingencies. However, I am of the view that these approaches merely mask the problem: how can the Court embrace pay inequity between males and females? I cannot apply a flawed process which perpetuates a discriminatory practice. The application of the contingencies, although in several cases reduce the wage gap, still sanction the disparity. ${ }^{90}$
}

Margaret's ambition had been to become a physiotherapist and, in Alberta, the wages of unionized physiotherapists employed in a hospital setting do not reflect the gender wage gap. Justice Johnstone instructed counsel to calculate lost earning capacity, including positive and negative contingencies, using the earnings of male physiotherapists employed in Alberta hospitals. ${ }^{91}$ The issue on appeal was not the base income used, but Justice Johnstone's decision not to determine negative contingencies based upon Margaret being female.

In cross-examination, Margaret was asked if prior to her injury she had wanted to have multiple children. She expressed that although it had been her "ideal wish," and that she had "maybe thought" of staying home with kids until they reached grade school, no "concrete plans" were made. ${ }^{92}$ The young woman was questioned on hypothetical motherhood with the 
goal of increasing her negative contingencies for non-participation in the workforce. Justice Johnstone dismissed this as evidence of Margaret's prospective behaviour and, in any event, she would not support future forecasting if it perpetuated the historical inequality between the earnings of men and women. ${ }^{93}$ She described the gendered method of assessing lost earning capacity as "an antiquated or limited judicial yardstick" that is overdue for replacement by "a more realistic, expansive measurement legally grounded in equality," which is a fundamental constitutional value in Canadian society. ${ }^{94}$

This approach to negative contingencies was overturned on appeal. While the common law must try to be consistent with the values of the Canadian Charter of Rights and Freedoms, ${ }^{95}$ the Alberta Court of Appeal held that Margaret's so-called "stated intentions" regarding children and childcare could not be ignored at the expense of restitutio in integrum. ${ }^{96}$ Writing for a unanimous bench, Justice Wittmann stated:

Determination of negative contingencies based upon a classification according to sex is not unreasonable in these circumstances. The situation is analogous to the use of actuarial tables based on sex, age or marital status to determine insurance premium rates for drivers of motor vehicles.

[T] he application of female contingencies would not perpetuate or sanction historical and societal discrimination. Further, wage statistics perpetuate noting. Valid data reflects historical reality. ${ }^{97}$

Margaret's damage for lost earning capacity was reduced by $\$ 158,733 .^{98}$

To an extent, this can be seen as a proper, formal application of tort law principles to create a damage award.${ }^{99}$ Compensatory damages must be quantified in a manner that is fair and reasonable to both parties, which requires an individualized approach. It is a biological reality that women give birth and men do not. It is also true that women are more likely than men to withdraw from paid employment for unpaid caregiving duties. ${ }^{100}$ To a greater extent, however, the Court's reasoning was built on a flawed analogy which ignores the high degree of discretion that actually is exercised in the assessment of damages. Most deleteriously, it endorses the practice of using a female's capacity for motherhood as a means of automatically reducing compensation for her injuries.

Zurich was cited in MacCabe as authority for the stated likeness between the determination of negative contingencies in personal injury claims and the calculation of car insurance premiums. ${ }^{101}$ Zurich involved a complaint under the Ontario Human Rights Code, 1981, challenging the insurance rating scheme of an automobile insurer that imposed the

MacCabe QB, supra note 3 at para 470.

Ibid.

Part I of the Constitution Act, 1982, being Schedule B to the Canada Act 1982 (UK), 1982, c 11

[Charter].

MacCabe CA, supra note 3 at paras 103, 107-108.

Ibid at paras 94, 124, cited in Cassels \& Adjin-Tettey, supra note 31 at 176.

MacCabe CA, ibid at paras 92, 128.

Steinebach CA, supra note 4 at para 65 , Groberman JA.

Statistical Report 2017, supra note 1 at 3.

Supra note 6. 
highest premium rates on single, male drivers under the age of 25. The Supreme Court held that it was a discriminative practice that was reasonable in the circumstances because (a) it was based on a sound and accepted insurance practice, and (b) there was no practical alternative. ${ }^{102}$ Writing for the majority, Justice Sopinka stated:

\footnotetext{
Human rights values cannot be over-ridden by business expediency alone. To allow "statistically supportable" discrimination would undermine the intent of human rights legislation which attempts to protect individuals from collective fault. To allow discrimination simply on the basis of statistical averages would only serve to perpetuate traditional stereotypes with all of their invidious prejudices. Society has decided not to hold the individual responsible for the sins of his or her "group" and the courts must seek to further rather than restrict this decision. It is therefore necessary to consider whether there was an alternative which in all the circumstances was practicable. ${ }^{103}$
}

Insurance is a risk based industry and premiums may vary according to the degree of calculated risk posed by the policy holder. This practice is sound if it was developed in good faith and was adopted for the purpose of achieving the legitimate business objective of charging premiums according to the corresponding risk. ${ }^{104}$ This risk is determined by actuarial evidence of "groups sharing characteristics material to the risk." 105 Not all individuals will share the risk-based characteristics attributed to them by their assigned group under the premium scheme, but this concern may be overridden by the impracticality of an individual assessment. ${ }^{106}$

In stark contrast, an individual assessment is exactly what is conducted in awarding compensatory damages. In the case of MacCabe, the Court held that there were no practical alternatives to using statistics predictive of time spent outside of the paid workforce, based upon the gender of the plaintiff, in the assessment of contingencies. ${ }^{107}$ The line of questioning directed at Margaret MacCabe and her membership in the female group were used to make a prediction about the negative forces that would reduce her capacity to earn an income because she is female. Discrimination in compensatory damages for personal injury, as per MacCabe, is permissible provided the individual fits the group which is being discriminated against. A difficulty with this approach is it shows excessive deference to a non-legal profession's method of assessment, which operates for different purposes and is guided by dissimilar principles. Unlike the insurance industry, damage for personal injury is not determined by risk assessments created to achieve legitimate business objectives. Instead, the courts strive for restitutio in integrum — insofar as money can — by providing full and fair indemnity to the injured person for losses caused by the specific tortfeasors. By contrast, private insurance companies are part of a capitalist system that is dictated by market forces. They spread the cost of liability over entire groups because it is efficacious from a dollarand-cents point of view. The courts, conversely, are not bound or driven by business interests in the assessment of lost earning capacity. They typically discourage even the use of rhetoric that suggests damages are "calculated" with mathematical precision, preferring room for 
judicial discretion thereby reducing the likelihood that the award is decided by a battle between expert witnesses. ${ }^{108}$ The law is clear that the task of the court is to assess damages, not to calculate them on a numerical formula like insurance underwriters.

MacCabe stands for the proposition that female reproductive ability and caretaking tendency is an essential factor in awarding damages for lost earning capacity. As set out by the Supreme Court of Canada in Athey v. Leonati, a hypothetical possibility will be taken into consideration provided it is a "real and substantial possibility and not mere speculation."109 A teenage girl's fantasy of having a family and perhaps providing her own childcare before returning to the workforce is far too speculative to be used as a negative contingency. The only substantiation in MacCabe was that women, not men, give birth, and overall more women than men provide childcare. That this was enough to reduce her entitlement to compensation for her quadriplegia appears to tip the balance towards the tortfeasor, when "[i]t is the pinning of that legal responsibility on the defendant that is at the heart of the tort system." 110

Ultimately, the Court of Appeal held that Charter considerations of fundamental equality with respect to lost earning capacity are secondary to principles of compensatory tort damage where the plaintiff indicates a desire for motherhood. ${ }^{111}$ Perhaps this was because the lower Court's references to Charter values were too vague; the reasons conjured the spirit of section 15 but did not cite the Charter directly. ${ }^{112}$ The judgment also was made several years before Grant v. Torstar Corp., when the Supreme Court of Canada clarified the scope of Charter scrutiny with respect to torts and the private law sphere. ${ }^{113}$ Irrespective, femalespecific negative contingencies should not be conflated to a status of furthering restitutio in integrum, particularly when they collide with constitutionally-protected equality rights.

The practical result of "female" negative contingencies is the denial of access to compensation that would be available to female plaintiffs if they were male. As no equivalent deductions are made to the damages of male plaintiffs, "female" negative contingencies

Toneguzzo-Norvell BCSC, supra note 17 at 14 (albeit not infant claims, recent cases reinforce the notion that the assessment of an award for lost earning capacity is not a purely mathematical exercise, although statistics can be helpful anchor points: Hajikolai v Lewis, 2015 BCSC 980; Mayer v Umabao, 2016 BCSC 506; Lampkin $v$ Walls, 2016 BCSC 1003. See also Mulholland (Guardian ad litem of) $v$ Riley Estate (1995), 12 BCLR (3d) 248.

$109 \quad[1996] 3$ SCR 458 at para 27.

110 Andrew Burrows, Understanding the Law of Obligations: Essays on Contract, Tort and Restitution (London: Hart Publishing, 1998) at 123 (writing in defence of the tort system of personal injury compensation and its principle of individual, legal responsibility).

$111 \quad$ MacCabe CA, supra note 3 at para 107.

112 Charter, supra note 95, s 15(1): "[e]very individual is equal before and under the law and has the right to the equal protection and equal benefit of the law without discrimination and, in particular, without discrimination based on race, national or ethnic origin, colour, religion, sex, age or mental or physical disability."

113 Grant v Torstar Corp, 2009 SCC 61 at paras 44, 46 [citations omitted]:

The common law, though not directly subject to Charter scrutiny where disputes between private parties are concerned, may be modified to bring it into harmony with the Charter. As Cory J. put it in Hill v. Church of Scientology of Toronto ... "Charter values, framed in general terms, should be weighed against the principles which underlie the common law. The Charter values will then provide the guidelines for any modification to the common law which the court feels is necessary."

As Iacobucci J. observed in R. v. Salituro, ... “[j] udges can and should adapt the common law to reflect the changing social, moral and economic fabric of the country." It is implicit in this duty that the courts will, from time to time, take a fresh look at the common law and reevaluate its consistency with evolving societal expectations through the lens of Charter values. 
continue the convention of imposing the costs of procreation entirely on women. Chief Justice Dickson held in Brooks v. Canada Safeway Ltd. that this imbalance is one of the most significant ways in which women have been disadvantaged in society. ${ }^{114}$ As the appellants in Brooks stated in their factum:

\footnotetext{
The capacity for pregnancy is an immutable characteristic, or incident of gender and a central distinguishing feature between men and women. A distinction based on pregnancy is not merely a distinction between those who are and are not pregnant, but also between the gender that has the capacity for pregnancy and the gender which does not. ${ }^{115}$
}

Capacity is also a question of making reasonable choices for oneself, rather than having them predestined by the courts based on historical inequality. While only women can give birth, "female" negative contingencies treat this biological ability as uniform in adversely affecting their capacity to earn an income. Much has been made in the case law of gender providing a "basis of realistic predictions about the future," but society's perceptions of gender are evolving at speeds which have never been anticipated by the judiciary. ${ }^{116}$ It is fair to assume that assessing the lost earning capacity of a person who is transgender or someone in a same-sex relationship was not in the minds of the justices of the "damage trilogy."

Women who choose to have children may return to paid employment immediately or shortly after childbirth, or not at all. Those who have children are now "concluding their childbearing in a relatively short time span," with increasing time spent in paid employment. ${ }^{117}$ The gender gap in time spent on unpaid labour in the home is beginning to converge among heterosexual couples between the ages of 20 and $29 .{ }^{118}$ Women's participation in child rearing is decreasing while men's participation is increasing across all age groups; the gap is expected to decrease significantly with the growing availability of "parental" leave options, as opposed to single-sex maternity leave. ${ }^{119}$ Today, more Canadian women are living alone, as part of a couple without children, or as part of a multigenerational family, than in a "mother, father and children" family unit that is presumed when "female" negative contingencies are applied. ${ }^{120} \mathrm{~A}$ variety of parenting and childcare arrangements exist in modern Canadian society and the increase in multigenerational households may be attributed to Canada's changing ethnocultural composition, as well as the rising cost of living and the unaffordability of childcare in some regions of the country. All of which can make withdrawing from the workforce financially foolish. By de-gendering damage contingencies, we are left with a more accurate reflection of the ever-evolving diversity of Canadian families.

[1989] 1 SCR 1219 at 1238 [Brooks] (decision cited by Justice Johnstone in MacCabe QB, supra note 3 at para 470 , regarding women's labour force participation and the historical wage disparity between men and women in general).

115 Brooks, ibid at 1244.

116 Tucker CA, supra note 2 at 533, MacEachern CJBC.

117 Statistics Canada, "Fertility: Fewer Children, Older Moms," (17 May 2018), online: <https://www. statcan.gc.ca/pub/11-630-x/11-630-x2014002-eng.htm>.

118 Katherine Marshall, "Generational Change in Paid and Unpaid Work," Catalogue No 11-008-X(Ottawa: Statistics Canada, 12 July 2011).

119 Ibid. See also Leanne C Findlay \& Dafina E Kohen, "Leave Practices of Parents After the Birth or Adoption of Young Children," Catalogue No 11-008-X (Ottawa: Statistics Canada, 30 July 2012).

120 Statistics Canada, "Families, Households and Marital Status: Key Results from the 2016 Census," Catalogue No 11-001-X (Ottawa: Statistics Canada, 2 August 2017). 


\section{The SOlution}

The solution is to retire female specific contingencies from infant personal injury claims. They sanction a worse quality of life for injured girls for the reason that on average women provide more unpaid, household labour. As with gender-neutral income statistics, genderneutral contingencies would result in greater consistency and predictability in the quantification of lost earning capacity. It is an opportunity to save costs and reduce litigation that is still wasted on establishing the likelihood of a girl's procreative and child caring future.

Gendered contingencies are rooted in assumptions about gender roles and notions of the "traditional" family that reflect less and less Canada's complex and evolving reality. Parenting creates both positive and negative effects on income generation that depend on the individual - one may be motivated to act upon more lucrative career opportunities to pay for the costs of children, while another may choose to provide their own childcare instead of hiring someone else to do it. The impact of these decisions, which are rarely taken lightly, are already built into average earnings statistics. ${ }^{121}$ Negative contingencies also assume that there are no sources of income available to those who withdraw from the workforce for parenting purposes, whether it be employment insurance, paid parental leave, work done remotely from home, or family income.

Bringing children into the world, and keeping them alive, is not something that women just indulge in on their own. In Steinebach, Justice Groberman in his separate reasons took issue with the treatment of child rearing as an activity having no economic value. He wrote that he was not of the view that the law requires child rearing to be treated as a non-economic activity; this is also not the reality for most parents who choose to withdraw from the workforce, either partially or fully, temporarily or permanently. ${ }^{122}$ Family law treats spouses as economic partners and has long recognized the value of child rearing. Perhaps in practice damage for lost earning capacity is actually meant to be a monetary representation of how comfortable a life the plaintiff would have had, separate from the non-pecuniary loss of enjoyment of life. This is not something dictated by gender. How these principles would apply to lost earning capacity was not explored in any depth because of a lack of evidence in this particular case. However, the presumption of gender equality in personal injury compensation for infants is a reasonable place to start.

There is no requirement that Canadian courts determine contingencies, whether positive or negative, by using gender. Much like the use of gendered statistics, it is a practice that has developed among provincial superior and appellate courts in the absence of a decision from the Supreme Court of Canada. Shortchanging females in personal injury litigation is not a matter of tort principle. The very essence of tort law rests on fundamental, long-term values that evolve and adapt to new conditions over the course of time. ${ }^{123}$ For example, marriage often was applied as a negative contingency for female plaintiffs before it finally began to 
fall out of practice in the 1990s. ${ }^{124}$ This was based on the expectation that women, upon marriage, would tend to their husband and the home in lieu of paid employment. A young male's potential for marriage, on the other hand, was viewed as a positive contingency that increased his damage for lost earning capacity. ${ }^{125}$ Just as these trends have fallen out of usage, so too should "female" negative contingencies related to possible motherhood.

\section{ConClusion}

Applying a cis-gendered, heteronormative lens to an infant's prospective earning capacity appears increasingly out of touch with every passing year. In December 2017, the British Columbia Supreme Court awarded compensatory damages to a plaintiff who had suffered a skull fracture as a 16-month-old in 2002 that caused lasting neurocognitive disabilities. ${ }^{126}$ The case is significant because the plaintiff, now a young adult, was in the process of gender reassignment to live as a female at the time of trial. Had litigation occurred when the plaintiff was still a child, male earning statistics and non-gendered contingencies presumably would have been used without an explanation. Justice Young chose to assess the lost earning capacity of the transgender plaintiff — who was once biologically male but who presents herself to the world as female and will present as female in the employment market - by using average male income statistics. ${ }^{127}$ Citing many of the cases discussed in this article, she rejected the use of female income statistics because they are far too imbedded with historical pay inequality. A 25 percent negative contingency was made for reasons unrelated to her injury, such as psychiatric and psychological challenges, as well as her reassignment surgery and a delayed entry into the workforce which would have occurred in any event. ${ }^{128}$ Additional negative contingencies that would have reflected the well-known "reality" of discrimination and job insecurity experienced by transgender people were not applied. Gender-neutral statistics may have provided a more well-rounded assessment than the maleonly statistics that were used. Nonetheless, the case represents the notion that gender and gender identity need not be treated as one's own "bad luck" in damage for lost earning capacity.

It is clear that gender must be eliminated from the assessment of an infant's lost earning capacity, whether as a beneficial or disadvantageous factor. A tortfeasor in a personal injury action is not responsible for the sociohistorical forces that have produced disparities in earnings. However, this does not mean gendered statistics — based on historical inequality and presumptions about the voluntary choice to withdraw from the workforce — are essential in awarding an injured girl compensation. The restitutio in integrum principle of tort damages can still be followed without such grossly inequitable concerns. The courts have

Downing (Guardian ad litem of) v Thomas Estate, 1988 CarswellBC 1188 (a 20 percent reduction in lost earning capacity was made in the case of a girl injured at age 13 "for those contingencies which might reduce her future income. These would include such matters as marriage, early retirement, and other circumstances where income assumed, may not actually come about" at para 54). See also Cassels \& Adjin-Tettey, supra note 31 at 178-79.

Lang $v$ Porter (1991), 57 BCLR (2d) 253 (CA), MacEachern CJBC ("[t]he plaintiff was a young man of only 20 years at the time of his injury. He had no special training or aptitude for anything but manual, physical labour ... [with only a] spotty teenage work history" but a positive contingency was applied for "the likelihood that a young man who has now taken on the responsibilities of a wife and family would probably settle down to a conventional economic life-style" at paras 34-35). MWS v ILM, 2017 BCSC 2309.

Ibid at paras 314,318 .

Ibid at para 319. 
developed an unarticulated practice of not identifying other classes of discrimination or financially-depressed groups in their analyses, yet singling out gender somehow remains acceptable. Specific gendered considerations can fall from favour, such as the marriage contingency. Those that remain are applied inconsistently, including income "gross ups" and the childcare contingency. These unnecessary barriers chip away at the quality of life of girls, injured through no fault of their own, while saying that their gender made them less capable of success anyway.

Assessing men and women differently implies a judgment of inferiority, reflected in lesser injury compensation for anyone who is not male. Injured girls would not be handed some sort of bonus by de-gendering lost earning capacity; they would be compensated deservedly for the life they could have had. 
[this page is intentionally blank] 